\title{
Analisis Manajemen Pengelolaan Keuangan Dan Administrasi Di Mini Market
}

\author{
${ }^{1}$ Marliza Safitri, ${ }^{2}$ Kasful Anwar US \\ 1-2 Jurusan Ekonomi Syariah, Fakultas Ekonomi dan Bisnis Islam, Universitas Negeri Sulthan Thaha \\ Saifuddin Jambi
}

\author{
Article history \\ Received: 10-03-2021 \\ Revised: 12-04-2021 \\ Accepted: 03-052021 \\ *Corresponding Author: \\ Marliza Safitri, \\ Kafsul Anwar US, \\ Jurusan Ekonomi Syariah, \\ Fakultas Ekonomi dan \\ bisnis Islam, \\ Universitas Negeri Sulthan \\ Thaha Saifuddin Jambi \\ Email: \\ marlizasafitri0b@gmail.c \\ $\underline{\mathrm{o}} \underline{\mathrm{m}}$
}

\begin{abstract}
Abstrak: Determinan Kinerja Keuangan pada Minimarket “ Alfamart” di Kabupaten Karanganyar. Penelitian ini memiliki tujuan untuk mengetahui pengaruh catatan akuntansi, sistem akuntansi, aksesibilitas keuangan, innovasi keuangan, praktik penanganan uang tunai, biaya transaksi, akuntabilitas, transparansi, dan SPI terhadap kinerja keuangan pada minimarket " alfamart” di Kabupaten Karanganyar. Populasi pada penelitian ini adalah seluruh karyawan minimarket " alfamart" di Kabupaten Karanganyar berjumlah 44 minimarket. Sampel dipilih dari purposive sampling, sampel yang digunakan 10 minimarket yang beroperasional 24 jam ( 80 responden). Sumber data adalah data primer (kuesioner).

Analisis ini menggunakan analisis regresi linier berganda dengan program SPSS versi 21. Penelitian menunjukan bahwa catatan akuntansi, praktik penanganan uang tunai, biaya transaksi, dan akuntabilitas memiliki pengaruh terhadap kinerja keuangan. Sedangkan, sistem akuntansi, aksesibilitas keuangan, innovasi keuangan, transparansi, dan SPI tidak memiliki pengaruh terhadap kinerja keuangan.
\end{abstract}

Kata Kunci : Manajemen, Pengelolaan Keuangan, Administrasi

\section{PENDAHULUAN}

Globalisasi ialah suatu peradaban manusia di era baru dimana ini akan terjadi suatu perubahan yang dapat dikatakan cepat dalam suatu kehidupan. Dalam berbagai kehidupan manusia mengalami suatu perubahan yang sangat drastis.

Salah satu perubahan ini merupakan perkembangan dalam suatu ilmu pengetahuan danatau teknologi yangdiperkirakan akan berkembang sangat pesat sekali. Maka perubahan ini mengakibatkan perubahan pola hidup manusia. Maka dengan ini teknologi telah mempengaruhi setiap fitur kehidupan manusia, telah mengubah tatanan sosial subsistem menjadi masyarakat sosial modern.

Keunikan bisnis membutuhkan pertimbangan yang dalam desain catatan akuntansi dan sistem akuntansi. Pada era baru peradaban manusia sistem pembayaran sekarang telah berkembang menjadi masyarakat tanpa uang tunai. Perubahan ini telah didorong oleh perkembangan yang tinggi dalam TIK.

Perluasan dalam pemanfaatan kerangka pembayaran tanpa uang tunai bertujuan untuk mengurngi biaya pengelolaan uang, memperluas efektivitas kerangka pembayaran dan mendorong pertimbangan moneter serta dalam masyarakat tanpa uang tunai. Para konsumen dapat membuat angsuran melalui web. Untuk menghidari ketidaksesuaian yang tidak diinginkan dalam perusahaan terdapat catatan akuntansi, sistem akuntansi, aksesibilitas keuangan, innovasi keuangan, praktik penanganan uang tunai, biaya transaksi, akuntabilitas, transparansi, dan sistem pengendalian internal.

Menurut (Ademola, dkk, 2012), pencatatan keuangan adalah pendasaran bisnis kiniberkembang untuk pertumbuhan dan keberlanjutan. Sementara itu, bisnis sangat tergantung pada catatan keuangan yang disimpan dalam pembukuan yang menunjukkan berbagai transaksi seperti penjualan, pembelian, pendapatan, dan pembayaran oleh individu atau organisasi. 
Menurut (Ismail \& King, 2007), pengembangan sistem akuntansi yang baik di UKM bergantung pada tingkat pengetahuan dan keterampilan akuntansi pemilik. Menurut (Solat, 2017), sistem pembayaran telah berkembang menjadi masyarakat tanpa uang tunai. Ini telah didorong oleh perkembangan tinggi dalam ICT, undang-undang Federal dan kehadiran industri keuangan baik publik dan swasta menawarkan layanan kliring moneter seperti bank, perusahaan kartu kredit dan rumah kliring otomatis.

Pengenalan sistem pembayaran tanpa uang tunai bertujuan untuk mengurangi biaya pengelolaan uang, memperluas efektivitas kerangka pembayaran dan mendorong pertimbangan moneter.

Menurut (Mardiasmo, 2006) Akuntabilitas ialah gambaran kemampuan yang berada dalam diri seseorang yang mampu memberikan pertanggungjawaban atas suatu keberhasilan atau suatu kegagalan dalam melaksanakan suatu misi dalam keinginan mencapai sesuatu pada sebelumnya, pertanggungjawaban ini merupakan pertanggungjawaban yang akan dilaksanakan secara periodik.

Menurut (Mustopa Didjaja, 2003) Transparansi merupakan sebuah keterbukaan pimpinan dalam memberikan informasi dalam merancang kebijakan-kebijakan terkait dengan aktivitas pengelolaan sumber daya antara pimpinan dengan karyawan.

Menurut (Hery, 2013) SPI ialah sebuah seperangkat danatau prosedur yang disusun sedemikian rupa guna untuk melindungi asset danatau kekayaan suatu perusahaan untuk menghindari adanya bentuk tindakan dalam penyalahgunaan yang akan menjamin adanya informasi akuntansi seuatu perusahaan yang akurat.

Tujuan penelitian untuk mengetahui suatu pengaruh catatan akuntansi, sistem akuntansi, aksesibilitas keuangan, innovasi keuangan, praktik penanganan uang tunai, biaya transaksi, akuntabilitas, transparansi, dan SPI terhadap kinerja keuangan pada minimarket " alfamart" di Kabupaten Karanganyar. Pada seksi berikutnya kami akan menyajikan kajian literatur yang akan diikuti dengan penjelasan mengenai metode. Maka, hasil penelitian kemudian dipresentasikan, didiskusikan, dan disimpulkan.

\section{Kajian Literatur \\ Literatur 1 teori agensi}

Teori agensi biasanya beberapa asumsi melandasinya. Asumsi-asumsi yang melandasi teori keagenan kita dapat membedakan teori agensi ini dalam tiga macam adalah, asumsi seseorang dalam sifat seorang manusia, asumsi seseorang dalam keorganisasian, dan asumsi seseorang dalam informasi (Eisenhardt, 1989). Terdapat sepuluh teori yang umumnya digunakan untuk membantu menjelaskan, yaitu :

\section{Teori 1 kinerja keuangan}

Kinerja keuangan ialah penganalisisan dilakukan agar dapat kita lihat sejauh mana prestasi akan dicapai dengan mudah dalam suatu perusahaan pada satu periode dapat mencerminkan seberapa tingkat suatu kesehatan perusahan atau dapat diartikan juga sebagai sesuatu yang juga dapat menggambarkan keuangan dalam perusahaan pada satu periode (Fahmi, 2011). Teori 2 catatan akuntansi

Catatan akuntansi merupakan beberapa kumpulan rekening-rekening yang terdapat pada Buku Besar selanjutnya secara periodic disusun kedalam sebuah laporan keuangan. Selain itu, pencatatan akuntansi, menyimpan dan memproduksi informasi keuangan berkaitan dengan 
posisi keuangan dan aliran transaksi keuangan. Aliran transaksi keuangan mencakup kas masuk (pendapatan) dan kas keluar (pengeluaran).

\section{Teori 3 sistem akuntansi}

Sistem akuntansi merupakan suatu gambaran metode dan prosedur organisasi yang mengibaratkan sebuah alat ukur dipakai mengorganisir danatau menyusun, megumpulkan, danjuga mengikhtisarkan terkait dengan seluruh transaksi-transaksi organisasi perusahaan, dimana seluruh yang berada dalam perusahaan dapat dipadukan sedemikian rupa (Nugroho, 2008)

\section{Teori 4 aksesibilitas keuangan}

Aksesibilitas keuangan merupakan ketercapaian yang berupa sebuah ketersediaan pasokan layanan keuangan yang berkualitas dengan biaya yang wajar, di mana relatif terhadap beberapa standar objektif, dengan biaya yang mencerminkan semua biaya uang maupun biaya non uang didefinisikan sebagai kualitas dan biaya yang adil (Hastomo \& Aras, 2018)

\section{Teori 5 innovasi keuangan}

Innovasi keuangan merupakan kelompokkan sebagai produk baru (misalnya, Hipotek subprime) atau layanan (misalnya, Internet banking) yang diperkenalkan untuk meningkatkan permintaan pasar atau untuk meningkatkan efisiensi lembaga keuangan. Selain itu, inovasi produk berkaitan dengan pengenalan kredit baru, deposito, asuransi, leasing, pembelian sewa dan produk keuangan lainnya. Kelompok lain adalah proses produksi baru (misalnya, lembaga kliring baru) yang telah mengarah pada peningkatan efisiensi dan perluasan pasar, ini termasuk otomatisasi kantor dan penggunaan komputer sementara kelompok lain adalah bentuk organisasi baru (misalnya, bank hanya Internet) yang berkaitan dengan perubahan dalam struktur bisnis atau menyiapkan struktur layanan yang sama sekali baru, ini termasuk bank-bank Internet saja.

\section{Teori 6 praktik penanganan uang tunai}

Praktik penanganan uang tunai merupakan suatu penelitian yang berisi tentang pendapat konsumen tentang keamanan system yang telah dilakukan dalam konteks pembayaran online tetapi variabel risiko yang dirasakan hanya dimodelkan sebagai konstruksi tunggal, yang gagal mencerminkan karakteristik risiko yang dirasakan konsumen (Hastomo \& Aras, 2018)

\section{Teori 7 biaya transaksi}

Biaya transaksi biasanya juga dapat diartikan sebagai biaya pengeluaran merupakan alat yang dipergunakan untuk menganalisis pengukuran efisiensi kelembagaan. Apabila dalam suatu biaya transaksi semakin tinggi akan semakin tidak efisien kelembagaan tersebut.

\section{Teori 8 akuntabilitas}

Akuntabilitas ialah gambaran kemampuan yang ada dalam diri seseorang yang akan mampu memberikan pertanggungjawaban atas suatu keberhasilan atau suatu kegagalan dalam melaksanakan suatu misi ada dalam keinginan mencapai sesuatu yang kita tetapkanpada sebelumnya, pertanggungjawaban ini merupakan pertanggungjawaban yang akan dilaksanakan secara periodik (Mardiasmo, 2006)

\section{Teori 9 transparansi}

Transparansi merupakan sebuah keterbukaan pimpinan dalam memberikan informasi dalam merancang kebijakan-kebijakan terkait dengan aktivitas pengelolaan sumber daya antara pimpinan dengan karyawan (Mustopa Didjaja, 2003)

\section{Teori 10 sistem pengendalian internal}

SPI ialah sebuah seperangkat danatau prosedur yang disusun sedemikian rupa guna untuk melindungi asset danatau kekayaan suatu perusahaan untuk menghindari adanya bentuk tindakan dalam penyalahgunaan yang akan menjamin adanya informasi akuntansi seuatu 
perusahaan yang akurat (Hery, 2013).

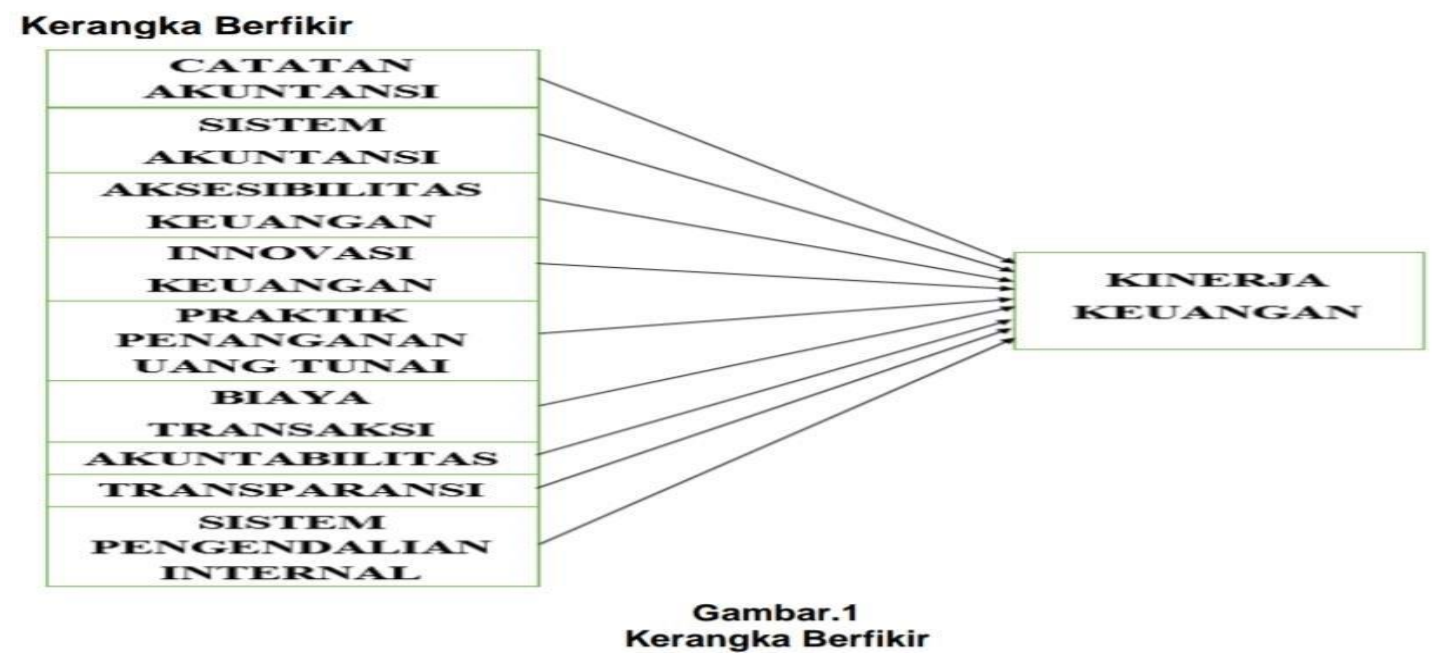

\section{Pengembangan hipotesis}

Pengaruh catatan akuntansi terhadap kinerja keuangan Menurut (Oladejo, 2008) pencapaian tujuan perusahaan sangat dipengaruhi oleh penerapan catatan akuntansi.

H1 : Catatan akuntansi memiliki pengaruh signifikan terhadap kinerja keuangan Pengaruh sistem akuntansi terhadap kinerja keuangan(Olatunji, 2013) meneliti dampak sistem akuntansi yang baik terhadap kinerja perusahaan dari perusahaan skala kecil dan menengah. Ini dilakukan dengan survei yang dilakukan melalui kuesioner dan dianalisis menggunakan FStatistic (ANOVA).

H2 : Sistem akuntansi memiliki pengaruh signifikan terhadap kinerja keuanganPengaruh aksesibilitas keuangan terhadap kinerja keuangan(Gerpott, Thomas, \& Hoffmann, 2008) yang berpendapat bahwa manfaat web (kualitas informasi, aksesibilitas informasi, berbagi informasi, dan manfaat transaksi) dan hambatan web (hambatan organisasi, kepercayaan, dan dukungan hukum) adalah faktor kunci yang mempengaruhi keuangan aksesibilitas dan karenanya mempengaruhi keputusan pelanggan untuk menggunakan sistem pembayaran tanpa uang tunai lebih lanjut menyatakan bahwa kenyamanan, operasi yang efisien, keamanan dan privasi, keandalan dan daya tanggap mempengaruhi kemampuan individu untuk mengakses keuangan.

H3 : Aksesibilitas keuangan mrmiliki pengaruh terhadap kinerja keuanganPengaruh innovasi keuangan terhadap kinerja keuangan(Juariah, 2014) bahwa inovasi keuangan dalam pembayaran telah mengurangi waktu antrian, meningkatkan kecepatan layanan dan mengurangi tingkat staf di luar waktu puncak dan sebagai hasilnya menyebabkan peningkatan penjualan sebagai dapat dioperasikan 24 jam dengan menggunakan kartu.

Temuan di atas lebih lanjut setuju dengan pengamatan dari studi sebelumnya oleh yang menunjukkan bahwa penggunaan uang tunai sesuai dengan pengambilan keputusan yang rasional. Adalah peran konsumen untuk memutuskan adopsi kartu pembayaran dan menggunakan alat pembayaran yang tersedia sesuai dengan transaksi dan karakteristik pribadi mereka, biaya tunai relatif dan penggunaan kartu serta preferensi.

H4 : Innovasi keuangan memiliki pengaruh terhadap kinerja keuanganPengaruh praktik penanganan uang tunai terhadap kinerja keuangan(Gerpott, Thomas, \& Hoffmann, 2008) yang menggunakan konstruk yang dianggap kredibilitas ', yang didefinisikan seseorang 
menggunakan mobile banking ini tidak akan selalumemiliki ancaman keamanan danatau privasi. Untuk ini, risiko keamanan / privasi seperti kurangnya kredibilitas.

Risiko waktu / kenyamanan mengacu pada hilangnya waktu dan ketidaknyamanan yang ditimbulkan karena pembayaran yang tertunda atau navigasi yang sulit. Dia lebih jauh mengeksplorasi hubungan antara pertumbuhan ekonomi dan sistem pembayaran elektronik sebagai cara untuk meninjau transisi saat ini ke ekonomi tanpa uang tunai di Nigeria. Hasilnya menggambarkan hubungan positif yang signifikan antara sistem pembayaran elektronik dan pertumbuhan ekonomi. Penelitian ini menghasilkan hasil yang sama seperti yang ditunjukkan oleh hubungan positif antara pembayaran tanpa uang tunai dan kinerja keuangan.

H5 : Praktik penanganan uang tunai memiliki pengaruh terhadap kinerja keuanganPengaruh biaya transaksi terhadap kinerja keuangan(Likert, 1986) mengeksplorasi hubungan fundamental antara pembayaran ritel elektronik dan pertumbuhan ekonomi. Menggunakan data dari 27 pasar Eropa selama periode 1995-2009 hasilnya migrasi secara keseluruhan. Sebuah studi yang dilakukan oleh Ighobor, \& PBB. (2017) pada pencarian Afrika untuk mendapatkan uang tunai menggambarkan bahwa biaya yang dirasakan memiliki signifikansi yang kecil dibandingkan dengan variabel lain seperti risiko yang dirasakan, kompatibilitas dan manfaat yang dirasakan. Selanjutnya, investigasi kualitatif pada studi yang sama dilakukan. Studi ini menunjukkan bahwa biaya yang dirasakan secara normal menjadi perhatian utama ketika teknologi diperkenalkan. Terlebih lagi, ketika kebutuhan mendadak atau darurat terjadi, manfaat utilitas lebih besar daripada masalah biaya.

H6 : Biaya transaksi memiliki pengaruh terhadap kinerja keuanganPengaruh akuntabilitas terhadap kinerja keuangan(Lucy, 2014) menentukan bahwa akuntabilitas dalam misi kita untuk mengelola keuangan dan sangat memiliki pengaruh signifikan terhadap kinerja keuangan pemerintah daerah.

H7 : Akuntanbilitas memiliki pengaruh terhadap kinerja keuanganPengaruh transparansi terhadap kinerja keuangan(Lucy, 2014) yang menemukan bahwa transparansi mengelola keuangan dan sangatmemiliki pengaruh signifikan terhadap kinerja keuangan pemerintah daerah.

H8 : Transparansi memiliki pengaruh terhadap kinerja keuanganPengaruh SPI terhadap kinerja keuangan(Lucy, 2014) yang menemukan dalam suatu SPI berpengaruhIterhadap kinerja keuangan suatu pemerintah

H9 : SPI memiliki pengaruh terhadap kinerja keuangan.

\section{METODE PENELITIAN}

Jenis Penelitian ini adalah kualitatif dengan variable dependen berupa Kinerja keuangan, sedangkan variable independen terdiri dari:
a. Catatan akuntansi
b. Sistem akuntansi
c. Aksesibilitas keuangan
d. Innovasi keuangan
e. Praktik penanganan uang tunai
f. Biaya transaksi
g. Akuntabilitas
h. Transparansi
i. Sistem pengendalian internal 
Populasi ini semua karyawan minimarket (alfamart) di Kabupaten Karanganyar yang berjumlah 44 minimarket. Sampel dari penelitian ini adalah 10 minimarket (alfamart) di Kabupaten Karanganyar yang berarti terdiri dari 80 karyawan yang menjadi sampel (Simple Random Sampling).

Peneliti menggunakan data primer. Seseorang yang akan diajukan dalam penelitian ini atau sering disebut seorang responden dari penelitian ini adalah 10 minimarket (alfamart) di Kabupaten Karanganyar (80 responden).

Instrumen penelitian ini data yang akan diperolehi melalui sebuah kuesioner yang disebar langsung terhadap responden yang dapat berupa data mengenai catatan akuntansi, sistem akuntansi, aksesibilitas keuangan, innovasi keuangan, praktik penanganan uang tunai, biaya transaksi, akuntanbilitas, transparansi, dan SPI terhadap kinerja keuangan.

Teknik Analisis Data

Uji Instrumen

a. Uji Validitas

Uji ini valid jika Rhitung > Rtable (Maryam R. S.,2011).

b. Uji Reliabilitas

Rumus Cronbach Alpha:R11= Keterangan::

R11 : Reliabilitas Instrumen

$\mathrm{K}$ : Banyaknya butir pertanyaan

$\sum \mathrm{St}^{2}$ : Jumlah variable butir

$\mathrm{St}^{2}$ : Total variable total

Uji Asumsi Klasik Regresi

a. Uji Normaitas Residual

Uji dilakukan agar supaya seorang peneliti mengetahui suatu nilai yang dihasilkan terdistribusikan normal atau tidak (Ghozali, 2012).

b. Uji Multikolinierita

Jika tolerance < 0,10 dan VIF $>10$ tidak terjadi multikolinieritas (Kalangi, 2015).

c. Uji Autokorelasi

Uji anggota menurut waktu danatau tempat. Uji yang baik tidak terjadi autokorelasi (Priyatno, 2014).

d. Uji Heteroskedastisitas

Uji heteroskedestisitas dilakukan agar supaya seorang peneliti mengetahui suatu nilai yang dihasilkan apakah terdapat variasi yang berbeda (Maryam R. S., 2011).

Analisis Regresi Linier Berganda

a. Uji Regresi

Persamaan Model :

$$
\mathrm{Y}=\alpha+\beta 1 . \mathrm{x} 1+\beta 2 . \mathrm{x} 2+\beta 3 . \mathrm{x} 3+\beta 4 . \mathrm{x} 4+\beta 5 . \mathrm{x} 5++\beta 6 . \mathrm{x} 6+\beta 7 . \mathrm{x} 7+\beta 7 . \mathrm{x} 8+\beta 7 . \mathrm{x} 9+\mathrm{e}
$$

Keterangan:

$\mathrm{Y}=$ Kinerja Keuangan

$\alpha=$ konstant

$\mathrm{X} 1$ = Catatan Akuntansi 
$\mathrm{X} 2=$ Sistem Akuntansi

$\mathrm{X} 3$ = Aksesibilitas Keuangan

$\mathrm{X} 4$ = Innovasi Keuangan

X5 = Praktik Penanganan Uang Tunai

X6 = Biaya Transaksi

$\mathrm{X} 7=$ Akuntabilitas

$\mathrm{X} 8=$ Transparansi

$\mathrm{X} 9=$ Sistem Pengendalian Internal

$\beta 1 \beta 2 \beta 3 \beta 4 \beta 5 \beta 4 \beta 5 \beta 6 \beta 7=$ Koefisien regresi parsial

$\mathrm{e}=$ Eror

b. Uji F

Menurut (Maryam R. S., 2011) uji F ditunjukan untuk seorang peneliti agarsupaya peneliti mengetahui dengan ini pengaruh secara keseluruan.

c. Uji-t

Uji-t ditujukan seorang peneliti agar supaya digunakan untuk mengujian nilai dengan cara parsial (Ghozali, 2012).

d. Koefisien Determinasi

Koofisien determinasi (R2) menurut (Ghozali, 2012) digunakan seorang peneliti agar supaya peneliti dapat dilihat besarnya variable (dependen) dijelaskan variable - variable (independen) yang terdapat pada model.

\section{HASIL DAN PEMBAHASAN}

1. Pengaruh catatan akuntansi terhadap kinerja keuangan(Uji-t), bahwa catatan akuntansi memiliki pengaruh signifikan terhadapkkinerja keuangan. Dilihat nilai sig dari catatan akuntansi 0,016 berarti sig < 0,05.Apabila perusahaan memiliki catatan akuntansi yang baik maka akan memiliki peran didalam kinerja keuangan, sejalan dengan penelitian (Ifeoma \& Okpala, 2019)

2. Pengaruh sistem akuntansi terhadap kinerja keuangan

(Uji-t), bahwa sistem akuntansi 0,958 berarti sig > 0,05 berarti kita simpulkan sistem akuntansi tidak memiliki pengaruh signifikan terhadap kinerja keuangan.Tidak sejalanidengan (Ifeoma \& Okpala, 2019). (Ifeoma \& Okpala, 2019)menyatakan bahwa sistem akuntansi yang sehat dari industri kecil dan menengah di Negara Bagian Anambra secara simultan akan sangat mempengaruhi. Tetapi, ini tidak menunjukan sistem akuntansi yang sehat dapat mempengaruhi kinerja keuangan.

Karena sistem akuntansi terkadang tidak bisa diandalkan. Karena, adanya beberapa poin ketidakyakinan yang membuat para pegawai memilih bahwa sistem akuntansi yang sehat tidak selalu mempengaruhi kinerjakkeuangan.

3. Pengaruh aksesibilitas keuangan terhadap kinerja keuangan(Uji-t),nbahwa aksesibilitas keuangan 0,737 berarti sig > 0,05 berarti kita simpulkan aksesibilitas keuangan tidak memiliki pengaruh signifikan terhadap kinerja keuangan.

Tidak sejalani dengan (Jumba \& Wepukhulu, 2019). (Jumba \& Wepukhulu, 2019)menyatakan bahwa aksesibilitas keuangan mempengaruhi kinerja keuangan. Peneliti juga menyimpulkan masalah jaringan mengganggu pembayaran cashless memaksa pelanggan untuk melakukan pembayaran dengan pilihan pembayaran lain yang mungkin mahal. Namun, penelitian ini tidak menunjukan bahwa aksesibilitas mempengaruhi kinerja keuangan. Karena, jika terjadi gangguan pada pembayaran cashless maka mereka akan membayar dengan metode pembayaran lain dengan tarif yang lebih mahal. 
4. Pengaruh innoasi keuangan terhadap kinerja keuangan(Uji-t), innovasi keuangan tidak memiliki pengaruh signifikantterhadap kinerja keuangan. Dilihat nilai sig dari innovasi keuangan 0,709 berarti sig > 0,05.Dengan ini tidak sejalan dengan (Jumba \& Wepukhulu, 2019). (Jumba \& Wepukhulu, 2019) menyatakan bahwa innovasi keuangan mempengaruhi kinerja keuangan. Penelitian menunjukkan bahwa penjualan telah meningkat sebagai hasil dari inovasi dalam pembayaran yang pembayaran kartu kredit dan debet, pembayaran uang Mobile dan Internet Banking.

Hal ini juga menunjukkan bahwa inovasi dalam pembayaran telah mengurangi biaya operasional sehingga meningkatkan keuntungan untuk supermarket. Namun, penelitian ini tidak menunjukan bahwa innovasi keuangan mempengaruhi kinerja keuangan. Maka, akan terjadi dengan sistem pembayaran berbagai macam innovasi akan mempersulit kinerja keuangan danjuga akan memperlambat kinerja dalam pelayanan pembayaran.

5. Pengaruh praktik penanganan uang tunai terhadap kinerja keuangan

(Uji-t), praktik penanganan uang tunai 0,000 berarti sig $<0,05$ berarti kita simpulkan praktik penanganan uang tunai memiliki pengaruh signifikan terhadapkkinerja keuangan.

Berdasar hasil ini, apabila perusahaan memiliki praktik penanganan uang tunai yang baik akan selalu ingin meningkatkan kinerja keuangan dalam perusahaan. (Jumba \& Wepukhulu, 2019) menyatakan bahwa seseorang percaya bahwa menggunakan mobile banking tidak akan terus selalu memiliki suatu ancaman keamanan atau privasi.

Untuk penelitian ini, risiko keamanan / privasi seperti kurangnya kredibilitas. Risiko waktu / kenyamanan mengacu pada hilangnya waktu dan ketidaknyamanan yang ditimbulkan karena pembayaran yang tertunda atau navigasi yang sukar. Hasil ini sejalan dengan penelitian (Jumba \& Wepukhulu, 2019).

6. Pengaruh biaya transaksi terhadap kinerja keuangan

(Uji-t), biaya transaksi memiliki pengaruh signifikantterhadap kinerja keuangan. Dilihat nilai sig dari biaya transaksi 0,027 berarti sig $<0,05$ berarti kita simpulkan biaya transaksi memiliki pengaruh signifikantterhadap kinerja keuangan.

Berdasar hasil ini, apabila perusahaan memiliki biaya transaksi yang rendah akan terus selalu meningkatkan suatu kinerja keuangan perusahaan. (Jumba \& Wepukhulu, 2019) menyatakan bahwa para responden setuju bahwa perusahaan terus berinvestasi dalam pembayaran tanpa uang tunai untuk memastikan kemudahan pembayaran (rata-rata = 3,75 ; std dev $=0,88$ ) dan bahwa investasi dalam pembayaran tanpa uang tunai telah menghasilkan peningkatan penjualan (ratarata $=3,90$; std dev $=0,69$ ) dan pengurangan dalam biaya operasi (rata-rata $=3,33$; std dev $=0,78$ ).

Studi ini menunjukkan bahwa biaya akan dirasakan secara normal menjadi perhatian utama ketika teknologi diperkenalkan. Hasil ini sejalan dengan penelitian (Jumba \&Wepukhulu, 2019).

7. Pengaruh akuntabilitas terhadap kinerja keuangan

(Uji-t), akuntabilitas berpengaruh signifikan terhadappkinerja keuangan. Dilihat nilai sig dari akuntabilitas 0,004 berarti sig $<0,05$ berarti kita simpulkan akuntabilitas memiliki pengaruh signifikan terhadap kinerja keuangan.

(Karim \& Mursalim, 2019) menyatakan bahwa mempertanggungjawabkan suatukeberhasilan danatau kegagalan, dengan melalui kriteria suatu media pertanggungjawaban yang dilaksanakan secara berkala. Hasil ini sejalan dengan penelitian (Karim \& Mursalim, 2019). 
8. Pengaruh transparansi terhadap kinerja keuangan

(Uji-t), transparansi tidak memiliki pengaruh signifikan terhadap kinerja keuangan. Nilai sig sistem akuntansi 0,887 berarti sig > 0,05.Dengan ini, tidak sejalan dengan (Karim \& Mursalim, 2019). (Karim \& Mursalim, 2019) menyatakan bahwa menyediakan media informasi dengan ini maka akan sangat membantu kinerja keuangan pada perusahaan. Namun, tidak menunjukan penelitian ini bahwa transparansi dapat mempengaruhi kinerja keuangan. Karena, mereka berfikir bahwa kebijakan yang berkaitan dengan perusahaan tidak perlu dipublikasikan ke masyarakat. Karena, ini merupakan rahasia dalam perusahaan.

9. Pengaruh SPI terhadap kinerja keuangan

(Uji-t), SPI tidak memiliki pengaruh signifikan terhadap kinerja keuangan. Dilihat nilai sig dari sistem akuntansi 0,135 berarti sig > 0,05.Dengan ini, tidak sejalan dengan (Karim \& Mursalim, 2019). (Karim \& Mursalim, 2019) menyatakan bahwa SPI yang diterapkan di Pendapatan Daerah Kota Gorontalo sebagaimana tujuanya SPI. Namun, tidak menunjukan bahwa SPI dapat mempengaruhi kinerja keuangan. Karena, mereka berfikir bahwa SPI sudah termasuk dalam kategori akuntabilitas diatas.

\section{KESIMPULAN}

Penelitian bertujuan untuk mengetahui dan menganalisis pengaruh catatan akuntansi, sistem akuntansi, aksesibilitas keuangan, innovasi keuangan, praktik penanganan uang tunai, biaya transaksi, akuntabilitas, transparansi, dan SPI terhadap kinerja keuangan. Variable dependentberupa kinerjakkeuangan. Variable independent yang digunakan dalam penelitian ini ialah catatan akuntansi, sistem akuntansi, aksesibilitas keuangan, innovasi keuangan, praktik penanganan uang tunai, biaya transaksi, akuntabilitas, transparansi, dan SPI. Populasi yang digunakan ialah seluruh karyawan minimarket " alfamart" di Kabupaten Karanganyar. Sampel 10 minimarket (alfamart) di Kabupaten Karanganyar yang berarti terdiri 80 responden (purposive sampling).

Dengan analisis regresi linier berganda. Simpulan catatan akuntansi, praktik penanganan uang tunai, biaya transaksi, dan akuntabilitas memiliki pengaruh signifikan terhadap kinerja keuangan. Sedangkan, sistem akuntansi, aksesibilitas keuangan, innovasi keuangan, transparansi, dan SPI tidak memiliki pengaruh signifikan terhadap kinerja keuangan.Penelitiantterbatas pada minimarket alfamart di Kabupaten Karanganyar yang menggunakan sampel penelitian di 10 alfamart diambil menurut jam operasional 24 jam, sehingga hasil penelitian ini tidak mecangkup setengah dari minimarket alfamart. Penelitian terbatas hanya melakukan di Kabupaten Karanganyar.

Peneliti selanjutnya diharapkan untuk menggunakan sampel minimal setengah dari jumlah seluruh alfamart di Kabupaten Karanganyar agar dapat digeneralisasikan sehingga dapat memperkuat hasil penelitian. Dan peneliti selanjutnya diharapkan meneliti minimarket di Kabupaten lain untuk menetapkan apakah temuan serupa akan diperoleh. Dan faktor yang mempengaruhi adopsi pembayaran cashless.

\section{DAFTAR PUSTAKA}

Ademola, dkk. 2012. Pencatatan Keuangan. Pengaruh Pembayaran Tanpa Uang Tunai terhadap Kinerja Keuangan Supermarket di Kabupaten Nairobi, Kenya.

Eisenhardt, K. M. 1989. Agency Theory : An Assessment and review. The Academy of Management Review (Jan): 57-74. 
Fahmi, I. 2011. Analisis Laporan Akuntansi. Bandung: ALFABETA.

Gerpott, T., Thomas, S., \& Hoffmann, A. 2008. "Intangible asset disclosure in the telecommunications industry". Journal of Intellectual Capital, Vol. 9 No. 1, pp. 3761.

Hastomo, A. D., \& Aras, M. 2018. Pengaruh Sosialisasi Masyarakat Cashless terhadap Kultur Transaksi Trust di Jakarta. Indonesia: Humaniora, 9(1),1-13.

Hery. 2013. Auditing (Pemeriksaan Akuntansi I), Cetakan Pertama. Jakarta: CAPS.

Ifeoma, L., \& Okpala. 2019. Pengaruh Catatan Akuntansi pada Kinerja Keuangan Industri Kecil dan Menengah di Nigeria. Jurnal International Tren dalam Penelitian dan Pengembangan Ilmiah (IJTSRD).

Ismail, \& King. 2007. Pengembangan sistem akuntansi. Pengaruh Catatan Akuntansi pada Kinerja Keuangan Industri Kecil dan Menengah di Nigeria.

Juariah, d. 2014. Pembelajaran Berbasis Lingkungan untuk Meningkatkan Hasil Belajar siswa pada Konsep keaneragaman Spermatophyta. Jurnal Biologi Edukasi Edisi 13. Vol 6. No 2.

Jumba, J., \& Wepukhulu, J. M. 2019. Pengaruh Pembayaran Tanpa Uang Tunai terhadap Kinerja Keuangan Supermarket di Kabupaten Nairobi, Kenya. Jurnal Internasional Penelitian Akademik dalam Bisnis dan Ilmu Sosial.

Karim, R. A., \& Mursalim. 2019. Pengaruh Akuntabiitas, Transparansi, dan Sistem Pengendalian Internal terhadap Kinerja Keuangan. Jurnal Ilmu Ekonomi.

Likert, R. 1986. Organisasi Manusia : Nilai dan Manajemen, Edisi Baru Terjemahan. Jakarta: Erlangga.

Lucy, A. 2014. Analisis Pengaruh Akuntabilitas dan Transparansi terhadap Kinerja Pemerintah Daerah. Jakarta.

Mardiasmo. 2006. Perwujudan Transparansi dan Akuntabilitas Publik melalui Akuntansi Sektor Publik: Suatu Sarana Good Governance. Jurnal Akuntansi Pemerintah vol. 2, no. 1, Mei 2006 hal 1-17.

Mustopa Didjaja. 2003. Manajemen Proses Kebijakan Publik Formulasi, Implementasi, dan Evaluasi Kinerja. Jakarta: LAN dan Duta Pertiwi.

Nugroho, W. 2008. Sistem Informasi Akuntansi. Jakarta: PT Glora Aksara Prima.

Nuryani Y. Rustaman, Ansi Suhandi.Solat. 2017. Sistem pembayaran tanpa uang tunai. Pengaruh Pembayaran Tanpa Uang Tunai terhadap Kinerja Keuangan Supermarket di Kabupaten Nairobi, Kenya. 
Oladejo, M. 2008. Micro Bussinesses and Enterpreneurship development; explanatory Accounting procedure. in Preceedings of International conference on Socio economic policies \& MDGs in Africa, Faculty of Management sciences: AAU. Akungba Akoko. onde state. Pp. 366372.

Olatunji, M. 2013. Interntional Journal On New Trends In Educational And Their Implications; Teaching and Assessing of Affective Characteristics: A Critical Missing Link In Online Education. Tersedia: www.Mengakses Aspek Afektif dan Kognitif: Riskan Qadar, 